\title{
Evaluation of a Commercial Extract of Giant Knotweed on Drought Tolerance of Impatiens
}

\author{
Diana R. Cochran ${ }^{1}$ \\ Department of Horticulture, Iowa State University, 125 Horticulture Hall, \\ Ames, IA 50011
}

Richard L. Harkess

Department of Plant and Soil Sciences, Mississippi State University, 117

Dorman Hall, Box 9555, Mississippi State, MS 39762

Patricia R. Knight

Coastal Research and Extension Center, Mississippi State University, 1815

Popps Ferry Road, Biloxi, MS 39532

Maria Tomaso-Peterson
Department of Plant Pathology and Entomology, 402 Dorman Hall, Box
9655, Mississippi State University, Mississippi State, MS 39762

Eugene K. Blythe

Coastal Research and Extension Center, Mississippi State University, South

Mississippi Branch Experiment Station, P.O. Box 193, Poplarville, MS 39470

Charles H. Gilliam

Department of Horticulture, Auburn University, 101 Funchess Hall, Auburn, AL 36849

Additional index words. biofungicides, Fallopia sachalinensis, Impatiens walleriana, plant protectants, Reynoutria sachalinensis, water use efficiency

Abstract. Regalia ${ }^{\circledR}$, a commercial extract of giant knotweed [Fallopia sachalinensis $\mathbf{F}$. Schmidt (synonyms: Reynoutria sachalinensis (F. Schmidt) Nakai, Polygonum sachalinense F. Schmidt, Tiniaria sachalinesis (F. Schmidt) Janch.)], was evaluated for its potential to enhance drought tolerance of container-grown impatiens (Impatiens walleriana Hook. f. 'Super Elfin XP White'). In two separate experiments, Regalia ${ }^{\circledR}$ was foliar-applied once a week for 4 weeks at four different rates $\left(0,5,10\right.$, or $\left.15 \mathrm{~mL} \cdot \mathrm{L}^{-1}\right)$. In Expt. 1, Regalia ${ }^{\circledR}$ was applied to impatiens grown under three target substrate volumetric water contents (TVWCs): $85 \%, 55 \%$, or $25 \%$. In Expt. 2, Regalia ${ }^{\circledR}$ was applied to impatiens watered with 1, 3, or 6 days between waterings (DBW). In Expt. 1, root dry weight $(R D W)$ of impatiens receiving applications of Regalia ${ }^{\circledR}$ at the $0.5 \times$ rate was greater compared with the $0.0 \times$ rate across all TVWCs. Additionally, soluble protein content was greater after Regalia ${ }^{\circledR}$ application at the $0.5 \times, 1.0 \times$, or $1.5 \times$ rates compared with the $0.0 \times$ rate for plants grown at 55\% TVWC. In Expt. 2, leaf greenness (SPAD) and leaf net photosynthetic rate (Pn) were greater with Regalia ${ }^{\circledR}$ applied at the $0.5 \times$ and $1.0 \times$ rates compared with the $0.0 \times$ rate, respectively. Soluble protein content was greater in impatiens treated with $\operatorname{Regalia}^{\circledR}$ at the $1.5 \times$ rate and $1 \mathrm{DBW}$ and the $0.5 \times$ rate with $3 \mathrm{DBW}$ compared with the $0.0 \times$ rate with 1 or $3 \mathrm{DBW}$. However, there was no indication that impatiens grown under different moisture levels had increased drought tolerance after application of Regalia ${ }^{\circledR}$.

A topic gaining interest in agronomic and horticultural crop production is the promotion of plant health and stimulation of plant immunity (American Phytopathological Society, 2009). Strobilurin fungicides were among the first class of fungicides to show increased yields through direct effects on photosynthetic efficiency and transpiration rate (BASF, 2009). Moreover, multiple reports have indicated pyraclostrobin, a strobilurin fungicide, increased nitrate reductase activity, increased antioxidant enzymes, increased stress tolerance, reduced the amount phytoalexins, which strengthen the plant's immune system (Konstantinidou-Doltsinis and Schmitt, 1998). After a plant has been affected by a biotic or abiotic agent, phytoalexins (antimicrobial compounds) are synthesized as a defense mechanism (Vasconsuelo and Boland, 2007). Some of these phytoalexins are lytic enzymes such as chitinases and glucanases, oxidizing agents, cell wall lignifications, pathogenesisrelated proteins, and transcripts of unknown functions (Mert-Türk, 2002). Additionally, Regalia ${ }^{\circledR}$ has been reported to increase chlorophyll content and the activity of peroxidases, polyphenoloxidases, and Phe ammonia-lyase (Daayf et al., 1997). Peroxidases are involved in lignin polymerization, crosslinkage of cell wall constituents, catabolism of auxin, formation of reactive oxygen species (ROS), and defense against pathogenic organisms (Bakalovic et al., 2006). Lignin polymerization provides rigidity and structural support to cell walls (Kärkönen and Koutaniemi, 2010). Under water stress, plant species with more elastic cells have relatively no change in cell water potential as water is removed; however, the more rigid a cell wall is, the greater the change in water potential as water is removed. Therefore, a cell with a more rigid cell wall increases water uptake without severe dehydration (Mengel et al., 2001; Salleo, 1983; Verslues et al., 2006). Thus, if application of Regalia $^{\circledR}$ increases peroxidase activity, it could result in heightened lignin polymerization and result in a more rigid cell wall preventing extreme cell dehydration.

With environmental stresses, governmental regulations, and increased human populations with limited water supplies (Burnett and van Iersel, 2008; Niu et al., 2008; Warsaw et al., 2009), plant producers and landscapers have had to follow stricter water use guidelines. Although it is known that some fungicides stimulate growth and may improve plant health (Balba, 2007), little research has evaluated these compounds for increasing ornamental plant tolerance to drought. Therefore, the objective of these experiments was to evaluate drought tolerance of impatiens treated with foliar applications of Regalia ${ }^{\circledR}$.

\section{Materials and Methods}

Plant material and culture. On 24 June 2010, impatiens seedlings were potted individually from a 288-plug flat into 15.24-cm (1.8-L) containers with Sunshine Mix 1 [70: 30 peat:perlite (v:v), nutrient charge, micronutrients, gypsum, calcium carbonate, wetting agent; SunGro Horticulture, Bellevue, WA] potting substrate. All containers were filled to the rim and lightly tapped twice on a hard surface to reduce air pockets. After potting, impatiens were watered, placed in a controlled environment greenhouse located on Mississippi State University's main campus, and grown for 4 weeks under $65 \%$ shade and $21.1 / 18.3{ }^{\circ} \mathrm{C}$ (day/night) set point temperatures. On 23 July 2010 [Expts. 1 and 2 (Run 1)] and on 3 Sept. 2010 [Expts. 1 and 2 (Run 2)], impatiens were moved to an inflated, double-layer polyethylene Quonset greenhouse located on Mississippi 
State University's R.R. Foil Plant Science Research Facility under $60 \%$ shade and $21.1 / 18.3^{\circ} \mathrm{C}$ (day/night) set point temperatures. Experiments were repeated twice and conducted in a similar manner: 27 July 2010 to 24 Aug. 2010 [Expts. 1 and 2 (Run 1)] and 7 Sept. 2010 to 4 Oct. 2010 [Expts. 1 and 2 (Run 2)].

Determination of substrate volumetric water content. Physical properties were determined for Sunshine Mix 1 (Hidalgo, 2001): $90.9 \%$ total porosity, $28.3 \%$ air space, $62.6 \%$ water-holding capacity, and $0.11 \mathrm{~g} \cdot \mathrm{cc}^{-1}$ bulk density. Substrate volumetric water content (VWC) was determined according to the instructions provided with a WaterScout SM100 Soil Moisture Sensor (Spectrum Technologies, Inc., Plainfield, IL) and fit to a regression model: VWC $=0.00076503 * \mathrm{MW}-0.79736(P=$ $0.0001 ; R^{2}=0.99$; where $\mathrm{MW}=$ target mass wetness, defined as a percentage).

Water stress and fungicide management. At initiation of Expt. 1, containers were determined to be at $100 \%$ actual VWC (AVWC) $1 \mathrm{~d}$ before the first application of Regalia ${ }^{\circledR}$. Based on AVWC, each container was hand-watered to the TVWC: $85 \%$ (control), $55 \%$, or $25 \%$. Containers maintained at $85 \%$ TVWC were not watered until $3 \mathrm{~d}$ after initial Regalia $^{\circledR}$ application (DAIR), whereas containers maintained at $55 \%$ or $25 \%$ TVWC were not hand-watered until 8 or 15 DAIR, respectively (Fig. 1). Four rates of Regalia ${ }^{\circledR}$ were applied based on the recommended label rate of $0.48 \mathrm{~g} \cdot \mathrm{L}^{-1}$ of active ingredient: $0.0 \times$ (water only), $0.5 \times\left(5 \mathrm{~mL} \cdot \mathrm{L}^{-1}\right), 1.0 \times(10$ $\left.\mathrm{mL} \cdot \mathrm{L}^{-1}\right)$, or $1.5 \times\left(15 \mathrm{~mL} \cdot \mathrm{L}^{-1}\right)$. Foliar applications of Regalia ${ }^{\circledR}$ were made once per week $3 \mathrm{~h}$ after watering containers to TVWC using a handheld sprayer (Model \# 20010 with a 301120-4 brass nozzle; Chapin International, Inc., Batavia, NY). Fertilizer was applied to the substrate at 200 ppm nitrogen using Peter's Professional 20N-8.8P-16.6K Peat-Lite Special (Scotts-Sierra, Inc., Marysville, $\mathrm{OH}$ ) at each watering. The experiment was conducted using a split plot design with the rate of Regalia ${ }^{\circledR}$ as the main plot factor in a randomized complete block design, TVWC as the subplot factor, with a three $\times$ four factorial treatment design and six single-pot replications for each treatment combination with two replications per block (total of three blocks). A single plant represented an experimental unit $(n=72)$.

Received for publication 11 Feb. 2014. Accepted for publication 27 June 2014.

We thank Paul Meintz, Geoff Denny, and Brien Henry for reviewing an early draft of this manuscript. We acknowledge Marrone Bio Innovations, Davis, CA, and the U.S. Department of Agriculture for funding this research.

Mention of a trademark, proprietary product, or vendor does not constitute a guarantee or warrantee of the product and does not imply its approval to the exclusion of other products or vendors that also may be suitable.

This article is a chapter of a dissertation submitted by Diana R. Cochran for the degree of $\mathrm{PhD}$ in Horticulture at Mississippi State University.

${ }^{1}$ To whom reprint requests should be addressed; e-maildianac@iastate.edu.

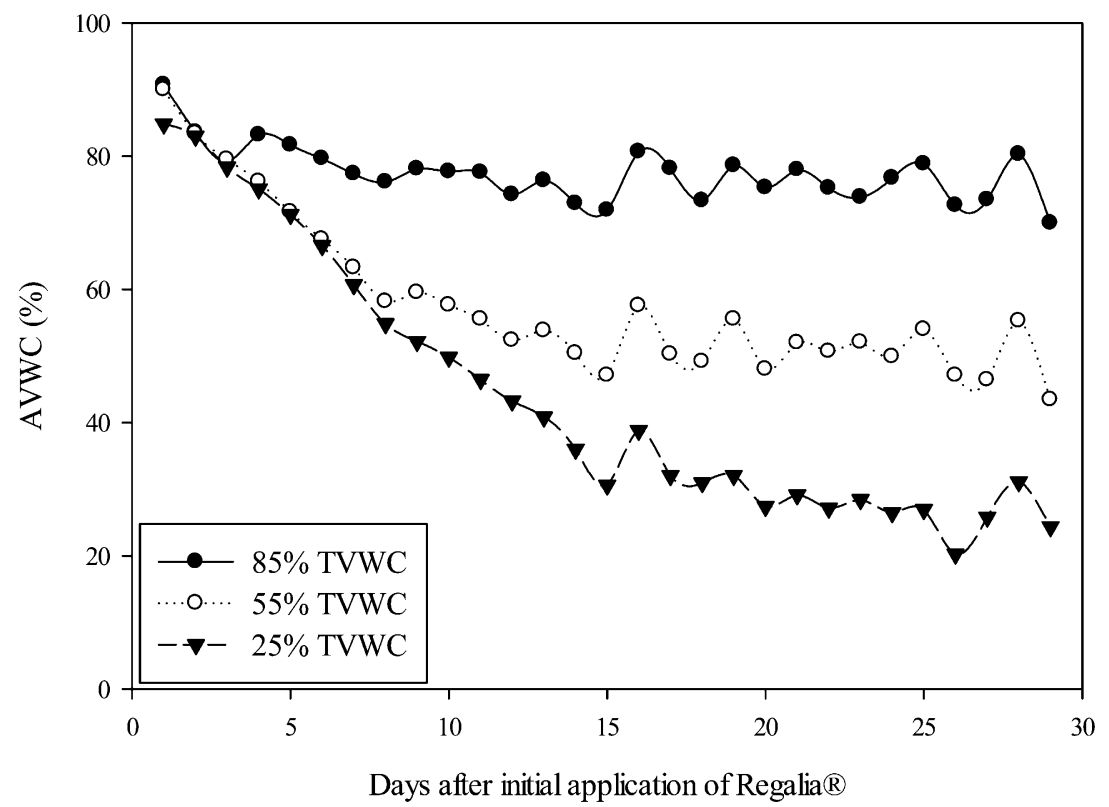

Fig. 1. Actual substrate volumetric water content (AVWC) after four weekly foliar applications of Regalia ${ }^{\circledR}$ to 'Super Elfin XP White' impatiens grown at three target substrate volumetric water contents (TVWCs). Data points represent daily averages pooled across experimental runs [27 July 2010 (Run 1) and 7 Sept. 2010 (Run 2)] and four rates $\left[0.0 \times, 0.5 \times, 1.0 \times\left(1.0 \times=10 \mathrm{~mL} \cdot \mathrm{L}^{-1}\right)\right.$, and $\left.1.5 \times\right]$ of Regalia ${ }^{\circledR}$ (Expt. 1; $\mathrm{n}=72$ ).

Table 1. Growth and water use efficiency of 'Super Elfin XP White' impatiens after four weekly foliar applications of Regalia ${ }^{\circledR}$ at four rates $\left(1.0 \times=10 \mathrm{~mL} \cdot \mathrm{L}^{-1}\right)^{\mathrm{z}}$ to plants grown in containers maintained at three target substrate volumetric water contents (TVWCs) (Expt. $1 ; \mathrm{n}=72$ ).

\begin{tabular}{lccccc}
\hline & FGI $(\mathrm{cm})^{\mathrm{y}}$ & SDW $(\mathrm{g})^{\mathrm{x}}$ & RDW $(\mathrm{g})^{\mathrm{w}}$ & WUE $\left(\mathrm{g} \cdot \mathrm{L}^{-1}\right)^{\mathrm{v}}$ & TWA $(\mathrm{L})^{\mathrm{u}}$ \\
\hline Rate & & & & & \\
$0.0 \times$ & 18.5 & 4.1 & $0.42 \mathrm{~b}^{\mathrm{t}}$ & 5.7 & 1.2 \\
$0.5 \times$ & 19.9 & 4.5 & $0.57 \mathrm{a}$ & 6.9 & 1.1 \\
$1.0 \times$ & 19.9 & 4.5 & $0.52 \mathrm{ab}$ & 6.5 & 1.2 \\
$1.5 \times$ & 17.2 & 3.6 & $0.41 \mathrm{~b}$ & 5.4 & 1.1 \\
& & & & & \\
TVWC & & & & & \\
$85 \%$ & $24.1 \mathrm{a}$ & $7.0 \mathrm{a}$ & $0.66 \mathrm{a}$ & $3.2 \mathrm{~b}$ & $2.3 \mathrm{a}$ \\
$55 \%$ & $19.9 \mathrm{~b}$ & $4.1 \mathrm{~b}$ & $0.48 \mathrm{~b}$ & $4.3 \mathrm{~b}$ & $1.0 \mathrm{~b}$ \\
$25 \%$ & $12.5 \mathrm{c}$ & $1.1 \mathrm{c}$ & $0.30 \mathrm{c}$ & $10.8 \mathrm{a}$ & $0.1 \mathrm{c}$ \\
& & & & & \\
Effects & & & & & \\
Rate & $0.1509^{\mathrm{s}}$ & 0.3437 & 0.0010 & 0.2484 & 0.7035 \\
TVWC & $<0.0001$ & $<0.0001$ & $<0.0001$ & $<0.0001$ & $<0.0001$ \\
Rate $\times$ TVWC & 0.8587 & 0.0552 & 0.8915 & 0.9937 & 0.8766 \\
\hline
\end{tabular}

${ }^{\text {ZInitial application of Regalia }}{ }^{\circledR}$ was made on 27 July 2010 (Run 1) or 7 Sept. 2010 (Run 2).

${ }^{\mathrm{y}} \mathrm{FGI}=$ final growth indices $[($ height + width + perpendicular width $) \div 3]$.

${ }^{\mathrm{x}} \mathrm{SDW}=$ shoot dry weight, oven-dried for $72 \mathrm{~h}$ at $65^{\circ} \mathrm{C}$.

${ }^{\mathrm{w}} \mathrm{RDW}=$ root dry weight, oven-dried for $72 \mathrm{~h}$ at $65^{\circ} \mathrm{C}$.

${ }^{v} \mathrm{WUE}=[(\mathrm{SDW}+\mathrm{RDW}) \div$ total water applied $]$.

"TWA $=$ total mean water applied.

'Means (within a column) pooled across experimental runs with the same letters within rate or TVWC are not statistically different according to the Holm-Simulation method $(\alpha=0.05)$.

${ }^{\text {s }} P$ value.

Expt. 2 was initiated similar to Expt. 1 and materials and methods were the same as in Expt. 1 except instead of maintaining daily TVWC, containers were watered with 1 (daily), 3, or $6 \mathrm{DBW}$. On the day of watering, containers were brought to $85 \%$ TVWC. Average AVWC during the duration of the experiment was $80 \%$ (1 DBW), 69\% (3 DBW), or $61 \%$ (6 DBW) (Fig. 2). The experiment was conducted using a split plot design with rate of Regalia $^{\circledR}$ as the main plot factor in a randomized complete block design, DBW as the subplot factor, with a three $\times$ four factorial treatment design and six single-pot replications for each treatment combination with two replications per block (total of three blocks). A single plant represented an experimental unit $(\mathrm{n}=72)$.

Growth index, biomass, and water use efficiency. At initiation of both experiments, initial growth index [IGI $=$ (height + width + perpendicular width) $\div 3$ ] was determined for each plant. At the termination of Expt. 1 on 8 Aug. 2010 and Expt. 2 on 4 Oct. 2010, final growth index [FGI $=($ height + width + perpendicular width) $\div 3$, shoot dry weight (SDW), RDW, and total growth $(\mathrm{TG}=\mathrm{FGI}-\mathrm{IGI})$ 
were determined for each plant. Shoots were harvested by cutting the entire plant at the soil line, removing the entire upper portion of the plant. Roots were harvested by first soaking the whole container with the substrate and roots in a 17.7-L container of tap water for a minimum of $8 \mathrm{~h}$ and then washing the substrate from the roots over a screen to catch all fallen roots. Shoots and roots were dried in a forced-air dryer at $65^{\circ} \mathrm{C}$ for $72 \mathrm{~h}$ before obtaining dry weights.

AVWC of each container was determined daily between 0600 and 0800 HR using a WaterScout SM100 Soil Moisture Sensor attached to a handheld FieldScout Soil Sensor Reader (Spectrum Technologies, Inc.). Daily readings were fit to the soil moisture curve and containers were hand watered to the TVWC. The amount of water applied per day per container was used to determine total water applied (TWA) over the 4-week period. Water use efficiency (WUE) was determined as described by Burnett and van Iersel (2008) with modifications using shoot and root dry weight $[\mathrm{WUE}=(\mathrm{SDW}+\mathrm{RDW}) \div$ total water applied].

Leaf greenness, photosynthesis, and midday stem water potential. Leaf greenness was measured using a handheld 502 SPAD chlorophyll meter (Konica Minolta, Osaka, Japan) at 2 and 4 weeks after initial application of Regalia ${ }^{\circledR}$ (WAIR). Leaf Pn was recorded at 2 and 4 WAIR using a CIRAS-2 portable photosynthesis system (PP Systems, Amesbury, MD) on the most recently matured leaf. Parameters were set at 2000 $\mu \mathrm{mol} \cdot \mathrm{m}^{-2} \cdot \mathrm{s}^{-1}$ photosynthetic photon flux density (using a tungsten halogen light attachment), ambient temperature, a relative humidity of $50 \%$ of ambient, and a $\mathrm{CO}_{2}$ concentration of $350 \mu \mathrm{mol} \cdot \mathrm{mol}^{-1}$ (per manufacturer's recommendation). Midday stem water potential $\left(\Psi_{\text {stem }}\right)$ (-Mpa) was measured using a Scholander-type pressure chamber according to Kjelgren et al. (2009). Leaves were wrapped first in plastic wrap and then in aluminum foil for at least $1 \mathrm{~h}$ before measurement.

Antioxidant enzyme extractions and assays. To evaluate metabolic changes induced after application of Regalia ${ }^{\circledR}$, leaf samples were collected at the end of each experiment, placed in Kraft \#1 coin envelopes (Quality Park Products, Minneapolis, MN), frozen immediately with liquid nitrogen, and stored at $-80{ }^{\circ} \mathrm{C}$ until analyzed for glutathione- $S$-transferase. Crude enzyme was extracted with $1 \mathrm{~mL}$ of a 50 mm sodium phosphate buffer ( $\mathrm{pH} 7.5)$ as previously described by Venisse et al. (2001), then centrifuged at $14,000 g_{n}$ at $4{ }^{\circ} \mathrm{C}$ until plant tissue was clearly separated from the 1 $\mathrm{mL}$ of extraction buffer (20 to $40 \mathrm{~min}$ ). Soluble protein (SP) content was determined for each sample according to Bradford (1976) using a Quick Start Bradford Protein Assay Kit 1 (Bio-Rad Laboratories, Hercules, CA).

Glutathione-S-transferase (GST) was assayed as previously described by Venisse et al. (2001) with some modifications. Samples (three replications from each rate $\times$ TVWC or rate $\times$ DBW combination) were analyzed in duplicates using an ELx808

Table 2. SPAD readings, ${ }^{\mathrm{z}}$ photosynthetic rate $^{\mathrm{y}}(\mathrm{Pn})$, and stem water potential ${ }^{\mathrm{x}}\left(\psi_{\text {stem }}\right)$ of 'Super Elfin XP White' impatiens after four weekly foliar applications of Regalia ${ }^{\circledR}$ at four rates $\left(1.0 \times=10 \mathrm{~mL} \cdot \mathrm{L}^{-1}\right)^{\mathrm{w}}$ to plants grown in containers maintained at three target substrate volumetric water contents (TVWC) (Expt. $1 ; \mathrm{n}=72$ ).

\begin{tabular}{|c|c|c|c|c|c|c|}
\hline & \multicolumn{2}{|c|}{ SPAD } & \multicolumn{2}{|c|}{$\operatorname{Pn}\left(\mu \mathrm{mol} \cdot \mathrm{m}^{-2} \cdot \mathrm{s}^{-1}\right)$} & \multicolumn{2}{|c|}{$\Psi_{\text {stem }}(-\mathrm{MPa})$} \\
\hline & \multicolumn{6}{|c|}{$\overline{\text { Weeks after initial application of Regalia }}{ }^{\circledR w}$} \\
\hline & 2 & 4 & 2 & 4 & 2 & 4 \\
\hline \multicolumn{7}{|l|}{$\overline{\text { Rate }}$} \\
\hline $0.0 \times$ & $48.0 \mathrm{~b}^{\mathrm{v}}$ & $48.0 \mathrm{ab}$ & 7.4 & 8.4 & -0.079 & -0.201 \\
\hline $0.5 \times$ & $52.2 \mathrm{a}$ & $50.7 \mathrm{a}$ & 11.9 & 9.0 & -0.117 & -0.052 \\
\hline $1.0 \times$ & $52.0 \mathrm{ab}$ & $47.3 \mathrm{ab}$ & 8.1 & 8.4 & -0.093 & -0.092 \\
\hline $1.5 \times$ & $48.5 \mathrm{ab}$ & $46.3 \mathrm{~b}$ & 4.9 & 7.0 & -0.070 & -0.185 \\
\hline \multicolumn{7}{|l|}{ TVWC } \\
\hline $85 \%$ & $54.5 \mathrm{a}$ & $55.2 \mathrm{a}$ & $12.0 \mathrm{a}$ & $11.7 \mathrm{a}$ & $-0.073 \mathrm{~b}$ & $-0.061 \mathrm{~b}$ \\
\hline $55 \%$ & $51.0 \mathrm{~b}$ & $51.4 \mathrm{~b}$ & $7.3 \mathrm{~b}$ & $9.7 \mathrm{~b}$ & $-0.120 \mathrm{ab}$ & $-0.078 \mathrm{~b}$ \\
\hline $25 \%$ & $45.0 \mathrm{c}$ & $38.9 \mathrm{c}$ & $4.9 \mathrm{~b}$ & $3.2 \mathrm{c}$ & $-0.081 \mathrm{a}$ & $-0.259 \mathrm{a}$ \\
\hline \multicolumn{7}{|l|}{ Effects } \\
\hline Rate & $0.0069^{u}$ & 0.0495 & 0.4386 & 0.7771 & 0.8189 & 0.1771 \\
\hline TVWC & $<0.0001$ & $<0.0001$ & $<0.0001$ & $<0.0001$ & 0.0410 & 0.0272 \\
\hline Rate $\times$ TVWC & 0.3390 & 0.2693 & 0.9620 & 0.3245 & 0.4960 & 0.2104 \\
\hline
\end{tabular}

${ }^{\text {zSPAD }}=$ leaf greenness was determined using a handheld 502 SPAD meter (Konica Minolta Optics Inc., Minolta, Japan)

${ }^{y}$ Leaf photosynthetic rate measured using a CIRAS-2 (PP Systems, Amesbury, MD).

x Stem water potential was measured by first wrapping the leaf in plastic film, then covering with aluminum foil, and held for at least $1 \mathrm{~h}$ before taking measurements.

${ }^{\mathrm{w}}$ Initial application of Regalia ${ }^{\circledR}$ was made on 27 July 2010 (Run 1) and 7 Sept. 2010 (Run 2).

"Means (within a column) pooled across experimental runs with the same letters within TVWC or rate are not statistically different according to the Holm-Simulation method $(\alpha=0.05)$.

u $P$ value.

Absorbance Microplate Reader with an ultraviolet filter (BioTek Instruments, Inc., Winooski, VT) at $340 \mathrm{~nm}$ for $10 \mathrm{~min}$. Each well contained $20 \mu \mathrm{L}$ of plant sample and $230 \mu \mathrm{L}$ reaction buffer $[0.1 \mathrm{M}$ potassium phosphate buffer [pH 6.5], 3.6 mM reduced glutathione molecular weight (MW) 307.3, $100 \mathrm{~mm}$ 1-chlor-2,4-dinitrobenzene (CDNB; MW 202.6)]. Activity was determined by following the formation of the conjugate of $1 \mu \mathrm{mol}$ of $\mathrm{CDNB}$ with reduced glutathione per minute at $\mathrm{pH} 6.5$ at $25{ }^{\circ} \mathrm{C}$ (extinction coefficient of $9.6 \mathrm{~mm}^{-1} \cdot \mathrm{cm}^{-1}$ ). Specific activity of GST was expressed as $\mu$ units $/ \mathrm{mg}$. Specific activity was achieved by reference to a standard curve developed from pure GST run on each plate.

Statistical analysis. Data were analyzed using linear mixed models with the GLIMMIX procedure of SAS (Version 9.2; SAS Institute Inc., Cary, NC) and with rate, TVWC, and DBW as fixed factors and block as a random factor. Data from each experimental run were pooled within an experiment when the run term was not significant at $\alpha=$ 0.05 . Pairwise treatment differences were obtained using the LSMEANS statement for main effects with mean separation according to the Holm-Simulation method $(\alpha=0.05)$. When there was a significant interaction (rate $\times$ TVWC or rate $\times$ DBW), the SLICEDIFF option was used to examine the pairwise comparisons and $P$ values adjusted using the Holm-Simulation method.

\section{Results}

Growth index, biomass, and water use efficiency (Expt. 1). Final growth index and SDW did not differ significantly among the
Table 3. Glutathione-S-transferase (GST) activity and soluble protein (SP) content in leaves of 'Super Elfin XP White' impatiens after four weekly foliar applications of Regalia ${ }^{\circledR}$ at four rates $\left(1.0 \times=10 \mathrm{~mL} \cdot \mathrm{L}^{-1}\right)^{\mathrm{z}}$ to plants grown in containers maintained at three target substrate volumetric water contents (TVWCs) (Expt. 1; $\mathrm{n}=36$ ).

\begin{tabular}{ccc}
\hline & $\begin{array}{c}\text { GST } \\
(\mu \text { units } / \mathrm{mg})\end{array}$ & $\begin{array}{c}\mathrm{SP} \\
\left(\mu \mathrm{g} \cdot \mathrm{mL}^{-1}\right)\end{array}$ \\
\hline Rate & & $1.2 \mathrm{~b}^{\mathrm{y}}$ \\
$0.0 \times$ & 92.4 & $2.2 \mathrm{a}$ \\
$0.5 \times$ & 65.5 & $2.6 \mathrm{a}$ \\
$1.0 \times$ & 33.2 & $2.5 \mathrm{a}$ \\
$1.5 \times$ & 80.2 & \\
& & \\
TVWC & & \\
$85 \%$ & $36.5 \mathrm{~b}$ & $2.7 \mathrm{a}$ \\
$55 \%$ & $50.5 \mathrm{~b}$ & $2.7 \mathrm{a}$ \\
$25 \%$ & $116.6 \mathrm{a}$ & $1.0 \mathrm{~b}$ \\
& & \\
Effects & & \\
Rate & $0.0787^{\mathrm{x}}$ & 0.0044 \\
TVWC & 0.0007 & $<0.0001$ \\
Rate $\times$ TVWC & 0.1606 & 0.0144 \\
\hline
\end{tabular}

${ }^{2}$ Initial application of Regalia ${ }^{\circledR}$ was made on 27 July 2010 (Run 2) and 7 Sept. 2010 (Run 2).

${ }^{y}$ Means (within a column) pooled across experimental runs with the same letters within rate or TVWC are not statistically different according to the HolmSimulation method $(\alpha=0.05)$.

${ }^{x} P$ value.

differing rates of Regalia ${ }^{\circledR}$ (Table 1). RDW was $36 \%$ greater after application of Regalia ${ }^{\circledR}$ at the $0.5 \times$ rate compared with the $0.0 \times$ rate; however, the $1.0 \times$ and $1.5 \times$ rates did not increase RDW. Additionally, differing levels of TVWC resulted in a significant effect on all parameters measured with decreased growth with decreasing TVWC. There were no significant interaction effects on growth 


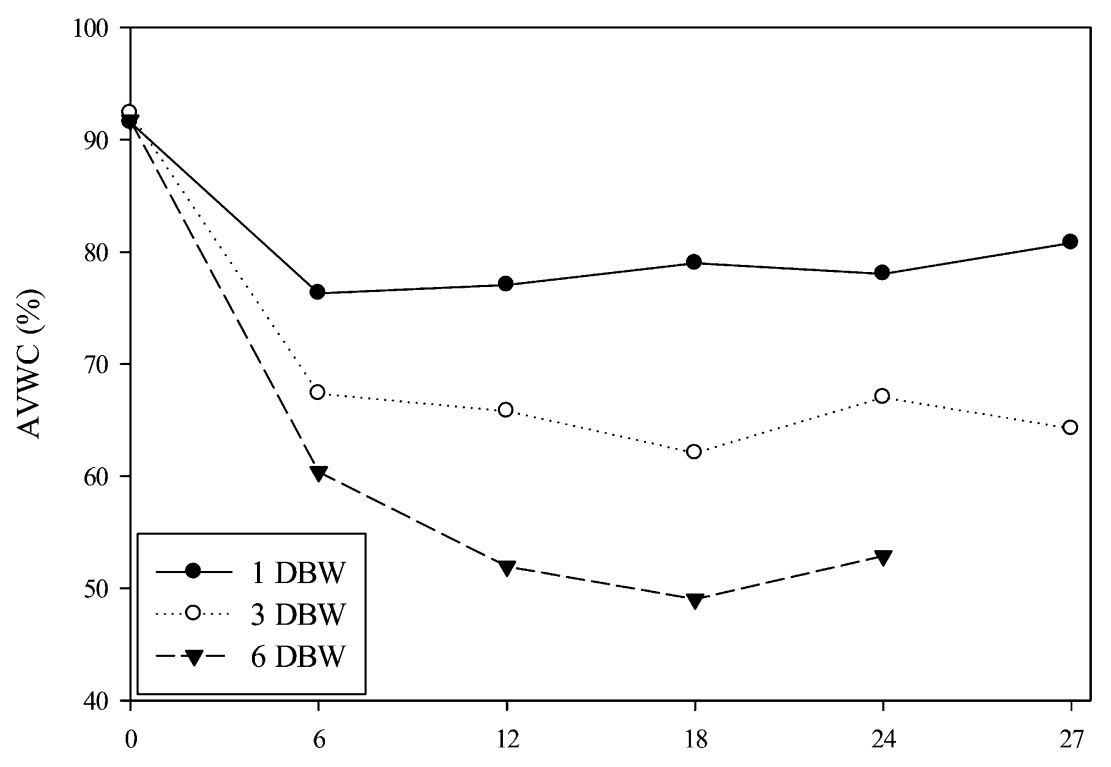

Days after initial application of Regalia ${ }^{\circledR}$

Fig. 2. Actual substrate volumetric water content (AVWC) after four weekly foliar applications of Regalia $^{\circledR}$ to 'Super Elfin XP White' impatiens with 1 (daily), 3, or $6 \mathrm{~d}$ between waterings (DBW). On each day of watering, containers were watered to $85 \%$ target substrate volumetric water content. Data points represent daily averages pooled across all experimental runs [27 July 2010 (Run 1) and 7 Sept. 2010 (Run 2)] and four rates $\left[0.0 \times, 0.5 \times, 1.0 \times\left(1.0 \times=10 \mathrm{~mL} \cdot \mathrm{L}^{-1}\right)\right.$, and $\left.1.5 \times\right]$ of Regalia ${ }^{\circledR}\left(\right.$ Expt. $\left._{2} ; \mathrm{n}=72\right)$.

Table 4. Growth and water use efficiency of 'Super Elfin XP White' impatiens after four weekly foliar applications of Regalia ${ }^{\circledR}$ at four rates $\left(1.0 \times=10 \mathrm{~mL} \cdot \mathrm{L}^{-1}\right)^{\mathrm{z}}$ to plants grown in containers with 1 (daily), 3 , or $6 \mathrm{~d}$ between waterings (DBW) (Expt. $2 ; \mathrm{n}=72$ ).

\begin{tabular}{lccccc}
\hline & FGI $(\mathrm{cm})^{\mathrm{y}}$ & SDW $(\mathrm{g})^{\mathrm{x}}$ & RDW $(\mathrm{g})^{\mathrm{w}}$ & WUE $\left(\mathrm{g} \cdot \mathrm{L}^{-1}\right)^{\mathrm{v}}$ & TWA (L) \\
\hline Rate & & & & & \\
$0.0 \times$ & 20.9 & 5.0 & 0.36 & 2.8 & 2.13 \\
$0.5 \times$ & 21.2 & 5.7 & 0.38 & 3.2 & 2.01 \\
$1.0 \times$ & 22.3 & 5.9 & 0.40 & 3.5 & 1.96 \\
$1.5 \times$ & 21.1 & 4.4 & 0.34 & 2.6 & 2.01 \\
& & & & & \\
DBW & & & & & \\
1 & $23.4 \mathrm{a}^{\mathrm{t}}$ & $6.6 \mathrm{a}$ & $0.46 \mathrm{a}$ & $3.4 \mathrm{a}$ & $2.09 \mathrm{a}$ \\
3 & $21.5 \mathrm{~b}$ & $5.2 \mathrm{~b}$ & $0.34 \mathrm{~b}$ & $2.8 \mathrm{~b}$ & $2.22 \mathrm{a}$ \\
6 & $19.3 \mathrm{c}$ & $3.9 \mathrm{c}$ & $0.30 \mathrm{~b}$ & $3.0 \mathrm{ab}$ & $1.77 \mathrm{~b}$ \\
& & & & & \\
Effects & & & & & \\
Rate & $0.6735^{\mathrm{s}}$ & 0.918 & 0.7920 & 0.5427 & 0.6445 \\
DBW & $<0.0001$ & $<0.0001$ & $<0.0001$ & 0.0044 & 0.0007 \\
Rate $\times$ DBW & 0.9610 & 0.8231 & 0.7685 & 0.7743 & 0.9690 \\
\hline
\end{tabular}

${ }^{\mathrm{z}}$ Initial rate of Regalia ${ }^{\circledR}$ was applied on 27 July 2010 (Run 1) and 7 Sept. 2010 (Run 2).

${ }^{\mathrm{y}} \mathrm{FGI}=$ final growth indices [(height + width + perpendicular width $) \div 3$ ].

${ }^{\mathrm{x}} \mathrm{SDW}=$ shoot dry weight, oven-dried for $72 \mathrm{~h}$ at $65^{\circ} \mathrm{C}$.

${ }^{\mathrm{w}} \mathrm{RDW}=$ root dry weight, oven-dried for $72 \mathrm{~h}$ at $65^{\circ} \mathrm{C}$.

${ }^{v} \mathrm{WUE}=[(\mathrm{SDW}+\mathrm{RDW}) \div$ total water applied $]$.

"TWA $=$ total mean water applied.

'Means (within a column) pooled across experimental runs with the same letters within rate or TVWC are not statistically different according to the Holm-Simulation method $(\alpha=0.05)$.

${ }^{\text {s }} P$ value.

index, biomass, WUE, or TWA. WUE was not significantly affected by rates of Regalia ${ }^{\circledR}$; however, WUE decreased with increasing TVWC. TWA was similar among rates of Regalia $^{\circledR}$ but increased with increasing TVWC.

Leaf greenness, photosynthesis, and midday stem water potential (Expt. 1). SPAD readings were greatest using the $0.5 \times$ rate at 2 WAIR compared with the $0.0 \times$ rate (Table 2 ). However, after 4 weeks, impatiens treated with the $0.5 \times, 1.0 \times$, or $1.5 \times$ rates had similar
SPAD readings compared with the $0.0 \times$ rate. At 2 and 4 WAIR, SPAD readings increased with increasing TVWC. Pn and $\Psi_{\text {stem }}$ were similar for impatiens treated with Regalia ${ }^{\circledR}$ at the $0.5 \times, 1.0 \times$, and $1.5 \times$ rates compared with the $0.0 \times$ rate at 2 and 4 WAIR. Additionally, Pn at 2 and 4 WAIR was greater with increasing TVWC. Similarly, $\Psi_{\text {stem }}$ at 4 WAIR was lower (more negative) in plants watered to $25 \%$ TVWC compared with plants watered to $85 \%$ or $55 \%$ TVWC.
Antioxidant enzyme extractions and assays (Expt. 1). GST activity in leaves of impatiens was similar after the application of Regalia ${ }^{\circledR}$ among all rates; however, GST did increase with decreasing TVWC (Table $3)$. There was no significant rate $\times$ TVWC effect on GST activity. Conversely, there was a significant rate $\times$ TVWC effect on SP content in impatiens leaves. SP content was greater in impatiens treated with the $1.5 \times$ rate compared with the $0.0 \times$ and $0.5 \times$ rates of Regalia ${ }^{\circledR}$ at $85 \%$ TVWC (Fig. 3). Additionally, impatiens treated with Regalia ${ }^{\circledR}$ at the $0.5 \times, 1.0 \times$, or $1.5 \times$ rates and watered to $55 \%$ TVWC had greater SP content compared with plants treated with the $0.0 \times$ rate and watered to $55 \%$ TVWC.

Growth index, biomass, and water use efficiency (Expt. 2). Rate of Regalia ${ }^{\circledR}$ did not have a significant effect on FGI, SDW, or RDW (Table 4). However, FGI, SDW and RDW were less for plants watered with 3 and 6 DBW treatments compared with plants watered daily (1 DBW). There was no significant rate $\times$ DBW effect on FGI, SDW, or RDW. WUE was similar among all rates of Regalia ${ }^{\circledR}$. However, impatiens watered with 1 DBW had greater WUE compared with plants watered with $3 \mathrm{DBW}$, yet TWA was similar between these two watering frequencies. WUE was similar between plants watered with 1 and $6 \mathrm{DBW}$, yet $18 \%$ more water was applied to plants watered with $1 \mathrm{DBW}$ than plants watered with $6 \mathrm{DBW}$.

Leaf greenness, photosynthesis, and midday stem water potential (Expt. 2). There was no significant effect of Regalia ${ }^{\circledR}$ rate on SPAD readings at 2 WAIR; however, plants receiving the $0.5 \times$ rate of Regalia ${ }^{\circledR}$ had greater SPAD readings compared with the $0.0 \times$ and $1.5 \times$ rates at 4 WAIR (Table 5). Additionally, at 2 and 4 WAIR, plants watered with 1 and 3 DBW had greater SPAD readings compared with plants watered at 6 DBW. Pn was unaffected by rate of Regalia ${ }^{\circledR}$ at 2 WAIR; however, at 4 WAIR, impatiens treated with the $1.0 \times$ rate of Regalia ${ }^{\circledR}$ exhibited greater Pn compared with plants treated with the $0.0 \times$ rate. At 4 WAIR, plants watered with 1 and 3 DBW exhibited greater Pn compared with plants watered with 6 DBW. There was no significant rate $\times$ DBW effect on Pn. Impatiens treated with Regalia $^{\circledR}$ at the $1.5 \times$ rate had $48 \%$ and $46 \%$ lower (more negative) $\Psi_{\text {stem }}$ compared with the $0.0 \times$ and $0.5 \times$ rates at 2 WAIR, respectively. However, at $4 \mathrm{WAIR}, \Psi_{\text {stem }}$ was similar among all rates.

Antioxidant enzyme extractions and assays (Expt. 2). GST activity was less in leaves of plants treated with Regalia ${ }^{\circledR}$ at the $0.5 \times, 1.0 \times$, and $1.5 \times$ rates compared with the $0.0 \times$ rate (Table 6). Leaves of impatiens watered with 3 or 6 DBW had similar GST activity compared with plants watered with 1 DBW. There was no significant rate $x$ DBW effect on GST. However, there was a significant rate $\times \mathrm{DBW}$ effect on $\mathrm{SP}$ content. SP content was $86 \%, 65 \%$, and $84 \%$ less in leaves of impatiens treated with 
Table 5. SPAD readings $\mathrm{z}^{\mathrm{z}}$ (LCC), photosynthetic rate ${ }^{\mathrm{y}}(\mathrm{Pn})$, and stem water potential ${ }^{\mathrm{x}}\left(\psi_{\text {stem }}\right)$ of 'Super Elfin XP White' impatiens after four weekly foliar applications of Regalia ${ }^{\circledR}$ at four rates $(1.0 \times=10$ $\left.\mathrm{mL} \cdot \mathrm{L}^{-1}\right)^{\mathrm{w}}$ to plants grown in containers watered with 1 (daily), 3 , or $6 \mathrm{~d}$ between waterings (DBW) (Expt. $2 ; \mathrm{n}=72$ ).

\begin{tabular}{|c|c|c|c|c|c|c|}
\hline & \multicolumn{2}{|c|}{ SPAD } & \multicolumn{3}{|c|}{$\operatorname{Pn}\left(\mu \mathrm{mol} \cdot \mathrm{m}^{-2} \cdot \mathrm{s}^{-1}\right)$} & $\Psi_{\text {stem }}(-\mathrm{MPa})$ \\
\hline & \multicolumn{6}{|c|}{${ }_{\text {Weeks after initial application of Regalia }{ }^{\circledR} \mathrm{w}}$} \\
\hline & 2 & 4 & 2 & 4 & 2 & 4 \\
\hline \multicolumn{7}{|l|}{ Rate } \\
\hline $0.0 \times$ & 53.5 & $54.2 \mathrm{~b}^{\mathrm{v}}$ & 11.0 & $6.5 \mathrm{~b}$ & $-0.065 \mathrm{~b}$ & -0.053 \\
\hline $0.5 \times$ & 53.5 & $57.5 \mathrm{a}$ & 13.6 & $9.1 \mathrm{ab}$ & $-0.068 \mathrm{~b}$ & -0.074 \\
\hline $1.0 \times$ & 54.5 & $55.5 \mathrm{ab}$ & 9.8 & $9.5 \mathrm{a}$ & $-0.084 \mathrm{ab}$ & -0.095 \\
\hline $1.5 \times$ & 53.8 & $53.1 \mathrm{~b}$ & 11.1 & $9.1 \mathrm{ab}$ & $-0.126 \mathrm{a}$ & -0.130 \\
\hline \multicolumn{7}{|l|}{ DBW } \\
\hline 1 & $55.3 \mathrm{a}$ & $56.6 \mathrm{a}$ & $13.0 \mathrm{a}$ & $10.6 \mathrm{a}$ & -0.069 & -0.077 \\
\hline 3 & $54.9 \mathrm{a}$ & $57.0 \mathrm{a}$ & $10.7 \mathrm{a}$ & $10.1 \mathrm{a}$ & -0.090 & -0.061 \\
\hline 6 & $51.3 \mathrm{~b}$ & $52.0 \mathrm{~b}$ & $10.4 \mathrm{a}$ & $4.9 \mathrm{~b}$ & -0.097 & -0.128 \\
\hline \multicolumn{7}{|l|}{ Effects } \\
\hline Rate & $0.7950^{\mathrm{u}}$ & 0.0045 & 0.9408 & 0.0365 & 0.0132 & 0.2716 \\
\hline DBW & $<0.0001$ & $<0.0001$ & 0.0442 & $<0.0001$ & 0.2788 & 0.0526 \\
\hline Rate $\times$ DBW & 0.6583 & 0.2073 & 0.9475 & 0.3078 & 0.3496 & 0.8283 \\
\hline
\end{tabular}

${ }^{\mathrm{z}}$ SPAD: Leaf greenness was determined using a handheld 502 SPAD meter (Konica Minolta Optics Inc., Minolta, Japan).

${ }^{y}$ Leaf photosynthetic rate measured using a CIRAS-2 (PP Systems, Amesbury, MD).

${ }^{\mathrm{x}}$ Stem water potential was measured by first wrapping the leaf in plastic film, then covering with aluminum foil, and held for at least $1 \mathrm{~h}$ before taking measurements.

winitial application of Regalia ${ }^{\circledR}$ was made on 27 July 2010 (Run 1) and Sept. 2010 (Run 2).

"Means (within a column) pooled across experimental runs with the same letters within TVWC or rate are not statistically different according to the Holm-Simulation method $(\alpha=0.05)$.

u $P$ value.

Table 6. Glutathione-S-transferase (GST) activity and soluble protein (SP) content in leaves of 'Super Elfin XP White' impatiens after four weekly foliar applications of Regalia ${ }^{\circledR}$ at four rates $\left(1.0 \times=10 \mathrm{~mL} \cdot \mathrm{L}^{-1}\right)^{\mathrm{z}}$ to plants grown in containers with 1 (daily), 3 or $6 \mathrm{~d}$ between watering (DBW) (Expt. 2; $\mathrm{n}=36$ ).

\begin{tabular}{ccc}
\hline & $\begin{array}{c}\text { GST } \\
\left(\mu \text { units·mg } \mathrm{mg}^{-1}\right)\end{array}$ & $\begin{array}{c}\mathrm{SP} \\
\left(\mu \mathrm{g} \cdot \mathrm{mL}^{-1}\right)\end{array}$ \\
\hline Rate & $62.4 \mathrm{a}^{\mathrm{y}}$ & $1.7 \mathrm{~b}$ \\
$0.0 \times$ & $18.9 \mathrm{~b}$ & $4.1 \mathrm{a}$ \\
$0.5 \times$ & $24.5 \mathrm{~b}$ & $2.3 \mathrm{~b}$ \\
$1.0 \times$ & $23.6 \mathrm{~b}$ & $4.5 \mathrm{a}$ \\
$1.5 \times$ & & \\
& & \\
DBW & 30.9 & 3.2 \\
1 & 31.0 & 3.6 \\
3 & 35.2 & 2.7 \\
6 & & \\
Effects & & 0.0013 \\
Rate & $<0.0001^{\mathrm{x}}$ & 0.3434 \\
DBW & 0.8234 & 0.0002 \\
Rate $\times$ DBW & 0.0717 & \\
\hline
\end{tabular}

${ }^{2}$ Initial application of Regalia ${ }^{\circledR}$ was made on 27 July 2010 (Run 1) and 7 Sept. 2010 (Run 2).

${ }^{y}$ Means (within a column) pooled across experimental runs with the same letters within rate or TVWC are not statistically different according to the HolmSimulation method $(\alpha=0.05)$.

${ }^{\mathrm{x}} P$ value.

the $0.0 \times, 0.5 \times$, and $1.0 \times$ rates compared with the $1.5 \times$ rate at $1 \mathrm{DBW}$, respectively (Fig. 4). Additionally, Regalia ${ }^{\circledR}$ applied at the $0.5 \times$ rate increased SP content by $77 \%$ compared with the $0.0 \times$ and $1.0 \times$ rates in plants watered with $3 \mathrm{DBW}$; however, there were no significant differences in SP content among the $0.0 \times, 1.0 \times$, and $1.5 \times$ rates.
$\Psi_{\text {stem }}$ recorded may not accurately reflect the degree of water stress. However, plants did show signs of wilting and reduced photosynthesis with decreasing TVWC. At the close of Expt. 1, impatiens maintained at 25\% TVWC were showing signs of water stress injury and, as a result, were producing more GST than impatiens maintained at $85 \%$ or $55 \%$ TVWC (Gill and Tuteja, 2010). Unlike Expt. 1, the antioxidant enzyme GST in Expt. 2 was less in leaves treated with Regalia ${ }^{\circledR}$ at the $0.5 \times, 1.0 \times$, and $1.5 \times$ rates compared with plants treated at the $0.0 \times$ rate. ROS are always present in the plant; however, only under elevated levels do they stimulate the production of antioxidant enzymes. Furthermore, several fungicides (carbendazim, tebuconazole, azoxystrobin, and JS399-19) have produced a decrease in $\mathrm{O}_{2}^{-}$levels in flag leaves of winter wheat (Zhang et al., 2010). Therefore, Regalia ${ }^{\circledR}$ may have protected against the formation of ROS, reducing the need for antioxidant enzymes. Regalia ${ }^{\circledR}$ applied at the $1.5 \times$ rate to plants maintained at $85 \%$ TVWC enhanced SP content compared with the $0.0 \times$ rate at $85 \%$ TVWC and the $0.5 \times, 1.0 \times$, or $1.5 \times$ rates enhanced SP content compared with the $0.0 \times$ rate at $55 \%$ TVWC, which is a typical response to application of Regalia $^{\circledR}$ (Marrone Bio Innovations, 2012). Examination of main effects indicated that plants treated with Regalia ${ }^{\circledR}$ at the $1.0 \times$ rate had a lower SP content than plants treated with the $0.5 \times$ and $1.5 \times$ rates, likely explained by the significant interaction between rate and TVWC. Plants treated with Regalia $^{\circledR}$ at the $1.0 \times$ rate and maintained at $55 \%$ TVWC had similar SP content to plants treated with the $0.5 \times$ and $1.5 \times$ rates and maintained at 55\% TVWC with all three of the aforementioned Regalia ${ }^{\circledR}$ rates resulting in a higher SP content than using the $0.0 \times$ rate. At $85 \%$ TVWC, plants treated with the $1.0 \times$ rate of Regalia ${ }^{\circledR}$ had similar SP content to plants treated with the $0.0 \times$ rate and the $1.5 \times$ rate, suggesting decreased TVWC was the contributing factor (Rahman et al., 2004). Conversely, SP content was greater in leaves of plants treated with the $1.5 \times$ rate in plants watered with $1 \mathrm{DBW}$ compared with plants treated with the $0.0 \times, 0.5 \times$, and $1.0 \times$ rates and watered with 1 DBW. Additionally, Regalia ${ }^{\circledR}$ applied at the $0.5 \times$ rate to plants watered with $3 \mathrm{DBW}$ resulted in greater SP content compared with plants treated with the $0.0 \times$ and $1.0 \times$ rates and watered with 3 DBW.

In conclusion, the objective of these experiments was to evaluate the effects of Regalia ${ }^{\circledR}$ on drought tolerance of impatiens and, based on the data presented here, there was no indication that Regalia ${ }^{\circledR}$ increased drought tolerance. Generally, moderately stressed (55\% TVWC) impatiens treated with Regalia ${ }^{\circledR}$ did have greener leaves (an indirect measurement of chlorophyll), a higher Pn, and greater soluble protein content, but this was not seen with plants maintained at $25 \%$ TVWC. Moreover, the contributing factor appeared to be VWC and not use of Regalia ${ }^{\circledR}$. However, these results may not be seen with 


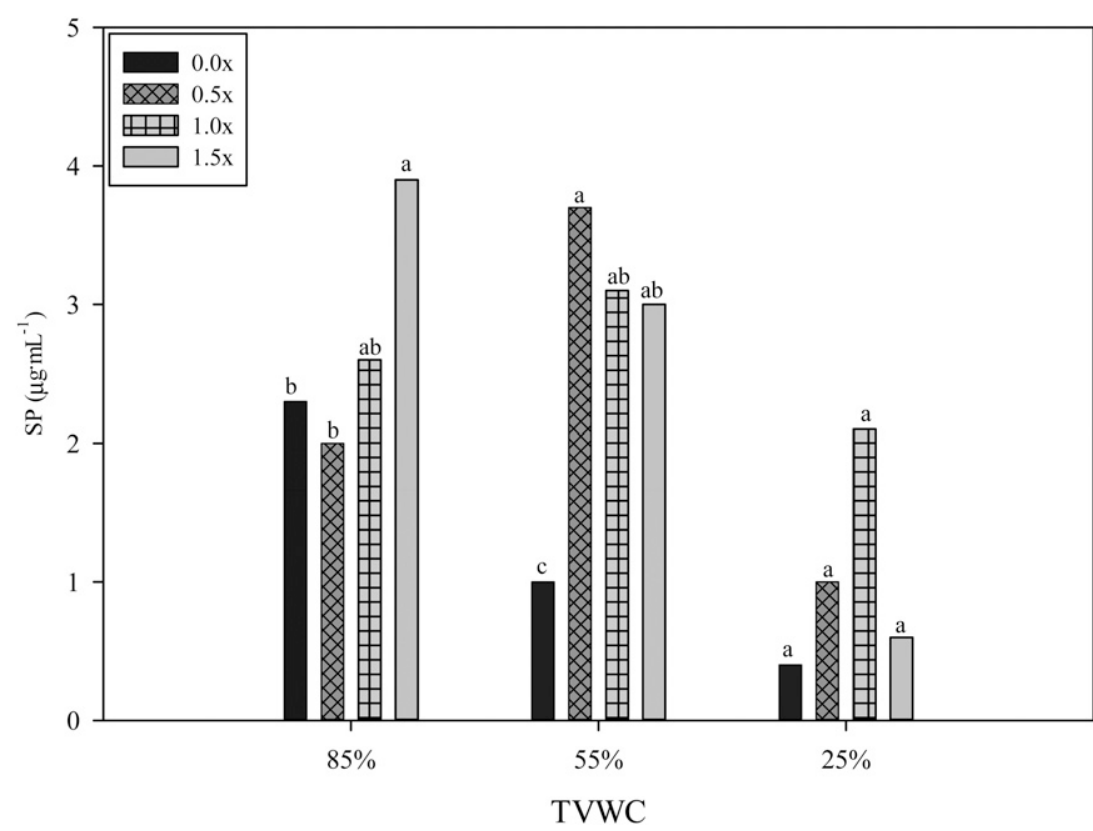

Fig. 3. Soluble protein (SP) content in leaves of 'Super Elfin XP White' impatiens after four weekly foliar applications of Regalia ${ }^{\circledR}\left[0.0 \times, 0.5 \times, 1.0 \times\left(1.0 \times=10 \mathrm{~mL} \cdot \mathrm{L}^{-1}\right)\right.$, and $\left.1.5 \times\right]$ to plants grown at three target substrate volumetric water contents (TVWCs). Means pooled across experimental runs [27 July 2010 (Run 1) and 7 Sept. 2010 (Run 2)] with the same letter are not significantly different according to the Holm-Simulation method $(\alpha=0.05)$ (Expt. $1 ; \mathrm{n}=36)$.

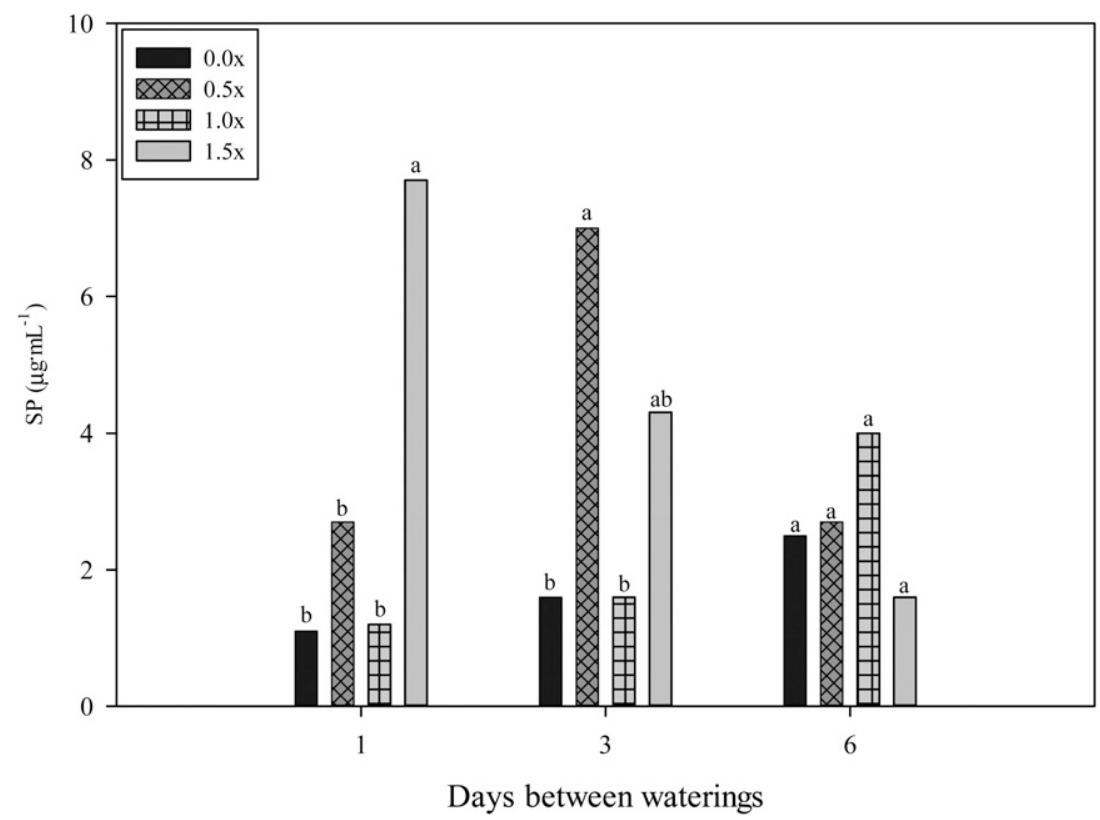

Fig. 4. Soluble protein (SP) content in leaves of 'Super Elfin XP White' impatiens after four weekly foliar applications of Regalia ${ }^{\circledR}\left[0.0 \times, 0.5 \times, 1.0 \times\left(1.0 \times=10 \mathrm{~mL} \cdot \mathrm{L}^{-1}\right)\right.$, and $\left.1.5 \times\right]$ to plants grown in containers with 1 (daily), 3, or $6 \mathrm{~d}$ between waterings (DBW). Means pooled across experimental runs [27 July 2010 (Run 1) and 7 Sept. 2010 (Run 2)] with the same letter are not significantly different according to the Holm-Simulation method, $\alpha=0.05$ (Expt. 2; $\mathrm{n}=36$ ).

every species or under every stress condition; therefore, individual assessment on plant stress tolerance or enhancements under stress should be determined before trying to use this product as a plant health protectant.

\section{Literature Cited}

American Phytopathological Society. 2009. The use of fungicides to promote plant physiological benefits in crops. 10 Feb. 2014. <http://www.apsnet. org/publications/webcasts/scientificpresentations/ Pages/FungicidesandPhysiologicalBenefits.aspx>.

Bakalovic, N., F. Passardi, V. Ioannidis, C. Cosio, C. Penel, L. Falquet, and C. Dunand. 2006. PeroxiBase: A class III plant peroxidase database. Phytochemistry 67:534-539.

Balba, H. 2007. Review of strobilurin fungicide chemicals. J. Environ. Sci. Health B 42:441451.
BASF. 2009. Headline ${ }^{\circledR}$ for improved plant health. Technical information bulletin. 1 Oct. 2009. $<$ http://www2.basf.us/corporate/f500_story.html>.

Bradford, M.M. 1976. A rapid and sensitive method for the quantitation of microgram quantities of protein utilizing the principle of protein-dye binding. Anal. Biochem. 72:248-254.

Burnett, S.E. and M.W. van Iersel. 2008. Morphology and irrigation efficiency of Gaura lindheimeri grown with capacitance sensor-controlled irrigation. HortScience 43:1555-1560.

Daayf, F., A. Schmitt, and R. Belanger. 1997. Evidence of phytoalexins in cucumber leaves infected with powdery mildew following treatment with leaf extracts of Reynoutria sachalinensis. Plant Physiol. 113:719-727.

Gill, S.S. and N. Tuteja. 2010. Reactive oxygen species and antioxidant machinery in abiotic stress tolerance in crop plants. Plant Physiol. Biochem. 48:909-930.

Hidalgo, P. 2001. Vermicompost as a substrate amendment for poinsettia and chrysanthemum production. PhD diss., Mississippi State University, Mississippi State, MS.

Kärkönen, A. and S. Koutaniemi. 2010. Lignin biosynthesis studies in plant tissue cultures. J. Integr. Plant Biol. 52:176-185.

Kjelgren, R., L. Wang, and D. Joyce. 2009. Water deficit stress responses of three native Australian ornamental herbaceous wildflower species for water-wise landscapes. HortScience 44: 1358-1365.

Köhle, H., K. Grossmann, T. Jabs, M. Gerhard, W. Kaiser, J. Glaab, U. Conrath, K. Seehaus, and S. Herms. 2002. Physiological effects of the strobilurin fungicide F 500 on plants, p. 6174. In: Dehne, H.W., U. Gisi, K.H. Kuck, P.E. Russell, and H. Lyr (eds.). Modern fungicides and antifungal compounds III. AgroConcept $\mathrm{GmbH}$, Bonn, Germany.

Konstantinidou-Doltsinis, S. and A. Schmitt. 1998 Impact of treatment with plant extracts from Reynoutria sachalinensis (F. Schmidt) Nakai on intensity of powdery mildew severity and yield in cucumber under high disease pressure. Crop Prot. 17:649-656.

Marrone Bio Innovations. 2011. New uses for Regalia ${ }^{\circledR}$ : Synergy, Cereals, Soils. 12 Apr. 2012. <http://www.abim.ch/fileadmin/documentsabim/presentations 2011/Session4/2_Julie_ Versman_ABIM2011.pdf>.

Marrone Bio Innovations. 2012. Marrone Bio Innovations’ Regalia ${ }^{\circledR}$ biofungicide label significantly expanded: EPA approval adds soil applications, instructions for yield improvement, new crops and target pathogens. 14 Aug. 2012. $<\mathrm{http}: / /$ marronebioinnovations.com/ news/download.php?id=144>.

Mengel, K., E.A. Kirkby, H. Kosegarten, and T. Appel. 2001. Principles of plant nutrition. 5th Ed. Kluwer Academic Publishers, Dordrecht, The Netherlands.

Mert-Türk, F. 2002. Phytoalexins: Defence or just a response to stress? J. Cell Mol. Biol. 1:1-6.

Nason, M.A., J. Farrar, and D. Bartlett. 2007. Strobilurin fungicides induce changes in photosynthetic gas exchange that do not improve water use efficiency of plants grown under conditions of water stress. Pest Mgt. Sci. 63:1191-1200.

Niu, G., D.S. Rodriguez, and W. Mackay. 2008. Growth and physiological responses to drought stress in four oleander clones. J. Amer. Soc. Hort. Sci. 133:188-196.

Rahman, S.M.L., W.A. Mackay, E. Nawata, T. Sakuratani, A.S.M.M. Uddin, and B. Quebedeaux. 2004. Superoxide dismutase and stress tolerance of four tomato cultivars. HortScience 39:983-986. 
Salleo, S. 1983. Water relations parameters of two Sicilian species of Senecio (groundsel) measured by the pressure bomb technique. New Phytol. 95:179-188.

Vasconsuelo, A. and R. Boland. 2007. Molecular aspects of the early stages of elicitation of secondary metabolites in plants. Plant Sci. 172:861-875.

Venisse, J., G. Gullner, and M. Brisset. 2001. Evidence for the involvement of an oxidative stress in the initiation of infection of pear by Erwinia amylovora. Plant Physiol. 125:2164 2172.

Verslues, P.E., M. Agarwal, S. Katiyar-Agarwal, J. Zhu, and J.K. Zhu. 2006. Methods and concepts in quantifying resistance to drought, salt and freezing, abiotic stresses that affect plant water status. Plant J. 45:523-529.

Warsaw, A.L., R.T. Fernandez, B.M. Cregg, and J.A. Andresen. 2009. Water conservation, growth, and water use efficiency of container-grown woody ornamentals irrigated based on daily water use. HortScience 44: 1308-1318.

Zhang, Y., X. Zhang, C. Chen, M. Zhou, and H. Wang. 2010. Effects of fungicides JS399-19, azoxystrobin, tebuconazole, and carbendazim on the physiological and biochemical indices and grain yield of winter wheat. Pestic. Biochem. Physiol. 98:151-157. 